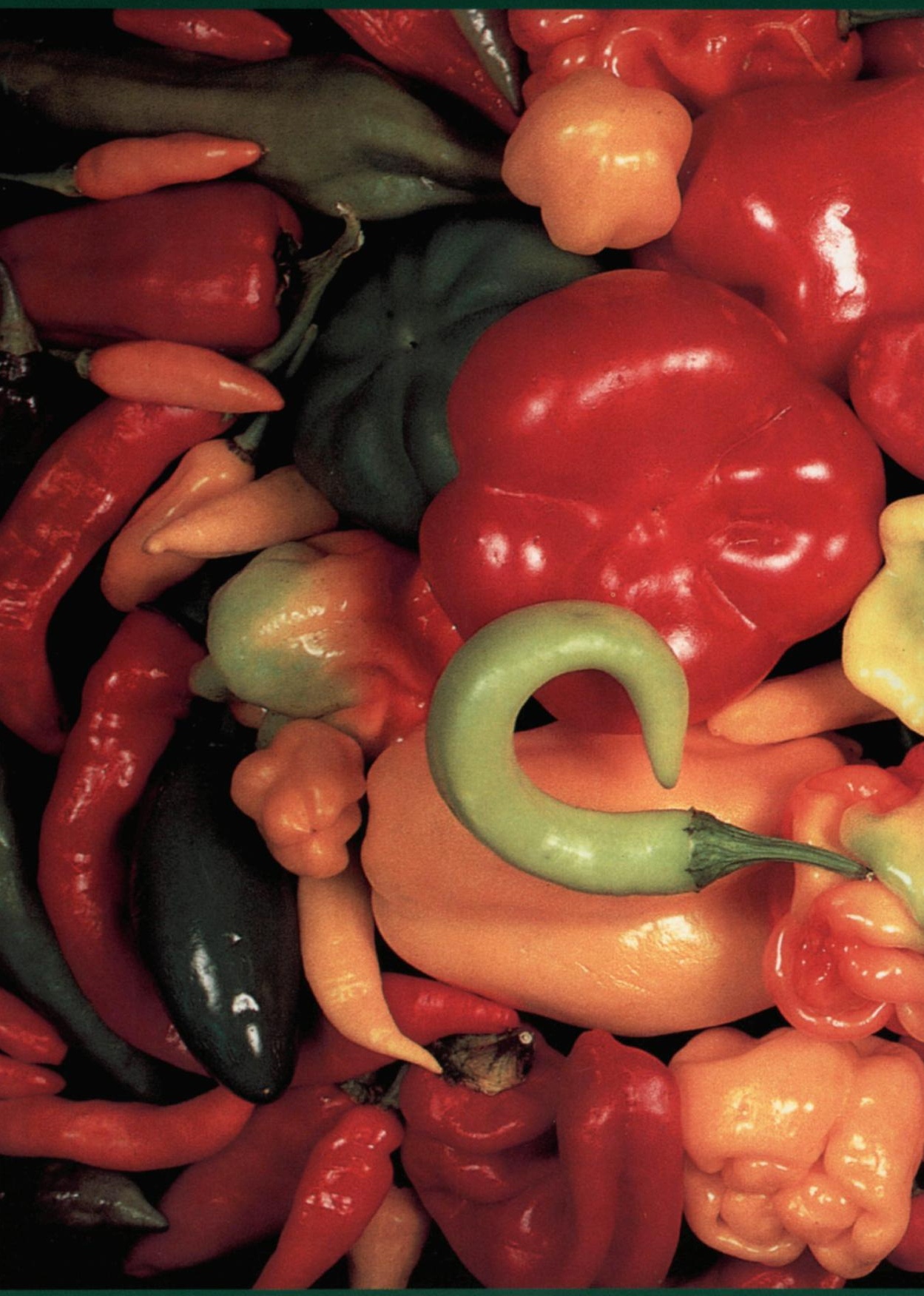




\section{The Pepper Lady's \\ Pocket Pepper Primer}

Courtesy of:

American Botanical Council 1-800-373-7105

www.herbalgram.org

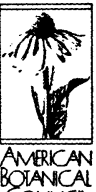

BOLANICAL Counca 

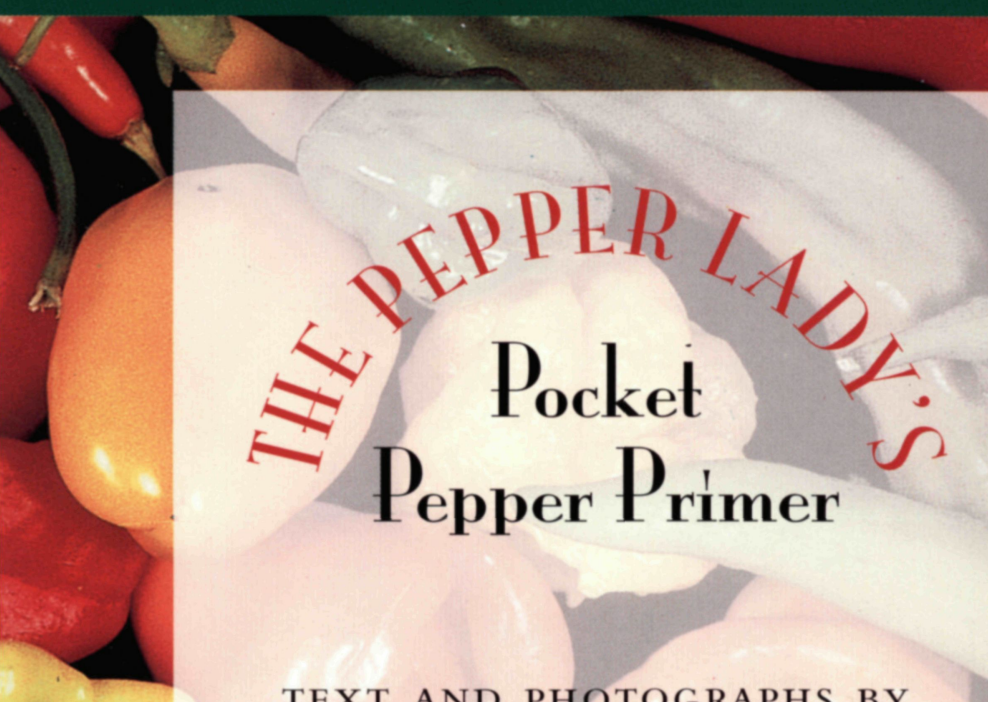

TEXT AND PHOTOGRAPHS BY

$$
\text { Jean Andrews }
$$

University of Texas Press AUSTIN \& 
The Pepper Lady ${ }^{\circledR}$ is a registered trademark

belonging to Jean Andrews.

Copyright (C) 1998 by Dr. Jean Andrews

Copyright (C) 1995 by Dr. Jean Andrews

Copyright (C) 1984 by Dr. Jean Andrews Smith

All rights reserved

Printed in China

First edition, 1998

Requests for permission to reproduce material from this work should be sent to Permissions, University of Texas Press, Box 7819, Austin, TX 78713-7819.

(2) The paper used in this publication meets the minimum requirements of American National Standard for Information Sciences - Permanence of Paper for Printed Library Materials, ANSI Z39.48-1984.

Designed by Ellen McKie

LIBRARY OF CONGRESS

CATALOGING-IN-PUBLICATION DATA

Andrews, Jean

The Pepper Lady's pocket pepper primer / text and photographs by Jean Andrews. - Ist ed.

p. $\mathrm{cm}$.

Includes index.

ISBN 0-292-70483-6 (pbk.)

I. Peppers-Identification. I. Title.

QK495.57A53 I997

$583^{\prime} .25$ - dc2 1

$96-51216$ 


\section{Dedicated to Peter Piper}




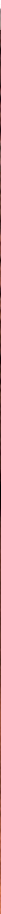

